\title{
Problémy a příležitosti environmentální výchovy v České
} republice

\section{Jan Činčera}

Envigogika 2006/I/1 - Recenzované články/ Reviewed Papers

Publikováno/Published 12. 12. 2006

DOI: http://dx.doi.org/10.14712/18023061.9

\section{Abstrakt:}

Otázky teorie a praxe environmentální výchovy v České republice týkající se vazby mezi cíli a prostředky, metodiky, evaluace a především absence významnějšího vědeckého výzkumu.

Klíčová slova: Vzdělávací cíle, metody, vzdělávací kontext, nástroje hodnocení

\begin{abstract}
:
The article analyses the weak points of environmental education in the Czech Republic. They are identified in the methods and poor evaluation strategies used by centres for environmental education and weak or non-existing research in this field at universities. In its last part it suggests areas for further and more detailed research.
\end{abstract}

\section{Key words:}

Educational goals, methods, educational context, evaluation instruments 


\section{Úvod}

Environmentální výchova v České republice dosáhla za šestnáct let své svobodné existence značných úspěchů. Vznik a rozvoj sítě středisek ekologické výchovy Pavučina, množství každoročně realizovaných programů a vydaných metodických materiálů jsou zřetelné indikátory postavení, kterého dosáhla. Na druhé straně je možné upozornit na setrvávající slabá místa $v$ její teorii i metodice, jejichž odstranění je předpokladem pro další kvalitativní rozvoj. Cílem článku je na několik takových slabých míst poukázat. Text je spíše vstupní úvahou indikující existující problémy a kladoucí otázky, které by měly být rozpracovány v dalších, navazujících prưzkumech.

\section{Práce s cíli}

Problémem řady programů environmentální výchovy je rozvržení a vytyčení jejich výchovně vzdělávacích cílů. Toto tvrzení samozřejmě nelze brát absolutně. Velmi dobře jsou cíle vymezeny například $v$ publikacích sdružení Člověk $v$ tísni, např́klad $v$ manuále Bohouš a Dáša proti chudobě (Nádvorník a Chára, 2006), kde jsou cíle přehledně rozděleny na znalostní (např. „Studenti uvedou výhody a nevýhody různých forem podpory rozvoje ze strany vyspělých zemí", "Studenti ukáží na príkladech pozitivní formy a výsledky rozvojové spolupráce."), postojové („Studenti jsou motivováni k podpoře rozvojové spolupráce.") a dovednostní (",Studenti spolupracují ve skupině, společně vytvoří poster dle daných kritérií."). Méně pečlivě, ale přesto jasně cíle formuluje Hruška (2006, s. 71), např. "účastník pochopí, jak se vzájemně ovlivňují vnější činitelé, jako jsou podvýživa, nemoci a živelné pohromy $v$ závislosti na velikosti zemědělské produkce". Naopak nepř́liš dobře jsou cíle formulovány v publikaci Pojd'me na to od lesa (NP, 2003). Např. cílem aktivity Dřevo je rozmanité (NP, 2003, s. 201) je "seznámit se s různými vlastnostmi dřeva", aktivity Kde to trvá déle (NP, 2003, s. 201) "ukázat důležitost jemného zpř́stupňování lesa". V prvním př́padě je cíl definován velice vágně a není zcela zřejmá jeho souvislost $s$ cíli environmentální výchovy. Ve druhém př́padě není cíl vymezen z pohledu studenta - není jasné, co si žáci mají z aktivity odnést.

$\checkmark$ jiných případech jsou sice cíle dobře naformulovány, ale $v$ rámci celého programu působí protichůdně. To se týká zejména cílů ovlivňujících postoje a hodnoty žáků, které mohou vycházet z rozdílných prístupů ekologické etiky. Tato rozdílnost potom vede k matoucímu "poselství" programů. Analyzujeme-li jinak velmi pečlivě zpracované kompetence absolventa programu environmentální výchovy, zpracované Jiř́m Kulichem ve Škole pro život (Daňková, s. 18-19), zjistíme, že v tematickém okruhu "Postavení člověka v př́rodě" se mezi cílovými kompetencemi objevuje "odmítnutí panského postoje člověka k prírodě" či "citlivý vztah vůči ostatním organismům". Oproti tomu v okruhu "Vzájemná závislost ekonomického rozvoje a životního prostředí" je jako cílové porozumění vyznačeno "chápání pojmů obnovitelné a neobnovitelné prrírodní zdroje". Většinou si málo uvědomujeme, že chápání zviŕat a rostlin jako přírodních zdrojů je právě důsledkem panského postoje $\mathrm{k}$ př́rodě, pro který je typické chápat svět jako skladiště, kterým můžeme disponovat. $\vee$ prípadě aktivit směřujících $\mathrm{k}$ rozvoji prvních dvou kompetencí, se žáci učí chápat zvíře jako "osobu", bytost s vlastní, intrinsickou hodnotou. V př́padě aktivit směřující ke třetí z uvedených kompetencí se ale ze zvířete stává prrírodní zdroj, tedy surovina, která má hodnotu pouze instrumentální, definovanou lidskými potřebami.

\section{Záměna cíle s tématem}

Dalším problematickým bodem $\mathrm{v}$ praxi organizací $\mathrm{i}$ pedagogů, zabývajících se environmentální výchovou, je určité pojmové nedorozumění, související se záměnou cíle environmentální výchovy a tématy jednotlivých programů. Environmentální výchova se 
historicky vyvíjela z výchovy k ochraně přírody, a proto v ní stále dominují programy, zaměřené na předávání znalostí o přírodě. Je ale každý program, který se zabývá prírodou, také environmentální výchovou?

Zalistujeme-li různými metodickými publikacemi, najdeme programy, jejichž cílem je např́klad naučit děti jak se řkne německy rybník, les či louka, změřit výšku stromu na principu jednoduché geometrie, dozvědět se, kolik procent České republiky pokrývají lesy či naučit se, jaké stromy $v$ lese rostou. Např. $v$ metodické publikaci Škola pro život najdeme jako př́klad vzorovou hodinu In the ZOO (Daňková, s. 76-77.), jejímž cílem je rozšiřit slovní zásobu žáků o některé druhy zvířat, procvičení gramatiky a rozvoj spolupráce a postřehu. Žáci srovnávají kartičky s českým a anglickým jménem zvířete, pak procvičují výslovnost a gramatiku čtením jednoduchých vět o zvířatech. $V$ jiné aktivitě, "Cesta do pravěku - výroba zkamenělin" (Daňková, s. 76-77.) je cílem orientovat se pomocí hry $v$ posloupnostech geologických období. Žáci si v ní prohlédnou geologickou mapu, hledají místa nálezů zkamenělin a poté vyrábí ze sádry zkameněliny vlastní.

Jde o environmentální výchovu, či nikoliv?

Podle rozšířeného názoru ano, protože děti si vytvářejí vztah k přírodě tím, že se o ní učí a dozvídají nové věci. To je ale argument velmi problematický, protože děti si nemusí nutně vytvářet kladný vztah ke všemu, o čem se učí a navíc souvislost mezi znalostmi, jednáním a postoji je obecně velmi pochybná. (Soukup, 2001) Pokud budeme chápat jako hlavní cíl environmentální výchovy změnu jednání či postojů lidí, může se jednat o programy, které $k$ tomuto cíli nesměřují a není je proto možné za environmentální výchovu považovat.

Výše uvedené aktivity samozřejmě mohou být efektivně využity pro dosahování vzdělávacích cílů biologie, cizího jazyka či matematiky. Sporné je jejich využití jako prostředku formování proenvironmentálních postojů a jednání. Rovněž to rozhodně neznamená, že žádné aktivity o přírodě $k$ těmto cílům nemohou směřovat: dưležité je pravděpodobně rozlišování mezi aktivitami, směřujícími na jedné straně $k$ dílčím detailưm a na straně druhé $k$ porozumění principům fungování přírody či k emocionálnímu formování vztahu k přírodě. (Matre, 1999) Je zjevné, že najít tuto hranici je jednou z výzev environmentální výchovy.

\section{Preference krátkých výukových programů}

Jádrem nabídky většiny středisek ekologické výchovy jsou krátké, zhruba dvouhodinové školní programy, nabízené školám. Taková forma je určitě vhodná, pokud škola dokáže zařadit program do vytvořeného smysluplného celku - projektu, plánu či integrovaného tematického celku. Předpokládejme například, že jedním z cílů plánu environmentální výchovy určité školy je to, aby děti porozuměly cyklům vody, energie a materiálu jako základním ekologickým principům života na Zemi a uvědomily si svoje místo $v$ nich. Plán se proto skládá z několika podoblastí zaměřených na toky energie, toky materiálu a vodní cyklus; integrující čtvrtou oblastí pak mưže být vztah k já - ekologické principy, které propojí předchozí témata s vlastním životem dětí. Některé podoblasti škola zajistí sama, některé si koupí v podobě krátkodobého programu střediska ekologické výchovy. Smysl dílčí aktivity tak bude určen nikoliv jen aktivitou samotnou, ale jejím kontextem: vztahem k dalšímu programu ve škole. Aby toto fungovalo, musela by se ale střediska bud' aktivně podílet na tvorbě školních programů, anebo by musela být schopna připravovat programy šité na míru jednotlivých škol. To je ale u nás bohužel velmi vzácné, protože většina škol je spokojena s tím, co jim střediska nabízí.

Programy nabízené středisky proto často představují nejpropracovanější formu environmentální výchovy, se kterou se děti setkají. Za hodinu a půl ale není možné zásadněji ovlivnit způsob, jakým se děti dívají na svět, jak v něm co hodnotí, jak rozumí 
svému místu na Zemi. Dochází k tak situaci, která rozhodně není optimální: školy vykazují plnění svých povinností $v$ oblasti environmentální výchovy účastí na několika často bezkoncepčně vybraných a nesouvisejících výukových programech. Z hlediska výkazů je to jednoduchá cesta, ale z hlediska smyslu daného prưřezového tématu je tento přístup nešt́astný.

Střediska ekologické výchovy by proto měla aktivně vstoupit do tvorby školních plánů environmentální výchovy a využít svého odborného potenciálu nikoliv k zajištování servisu školám, ale k partnerské spolupráci na vytvoření plánů, jdoucích od cílů k prostředkům. Měla by se pokusit nabízet spíše než sérii nesouvisejících krátkých programů větší celky - programy provázané, dlouhodobé projekty, pobytové akce.

\section{Slabá metodika projektů a školních plánů environmentální výchovy}

Praxe environmentální výchovy oprávněně zdůrazňuje význam rozsáhlejších celků, jako jsou projekty či ucelené školní plány environmentální výchovy. Jaká je ale úroveň jejich zpracování? V úvodním př́kladu se pokusíme ilustračně analyzovat nepublikovaný projekt studentky Technické univerzity v Liberci určený pro 1 . stupeň ZŠ "Ekologický výukový program - Naučná stezka". Žáci si podle autorky: "upevní vztahy mezi přirodním prostředím a společenským, nauči se postupy pro tvorbu optimálního životního prostředí, rozvoj po stránce komunikační a sociální".

Podle projektu studenti nejprve měli dostat pracovní list, ve kterém měli propojovat zviŕata s př́slušným lesním patrem. Následovala debata o typologii lesních pater, přičemž učitel měl připravenou správnou odpověd', kterou měli žáci uhodnout. Dál měli hledat semenáček buku a namalovat si ho. Na další zastávce v pracovním listu hledali chyby v zakreslení místa, kde žijí lesní zvírátka. Odpoledne měli sbírat to, co do přírody nepatří a třídit odpad. Následovalo poznávání bylin a živočichů podle obrázků. Procházka končila kreslenou reflexí.

Projekt či jakýkoliv dlouhodobý plán by měl začít s přesným vymezením cílů. Pokud ale cíle nejsou vymezeny nebo zůstávají v proklamativní obecné rovině ("aby měly děti vztah k přírodě a něco o ní věděly"), nemưže vzniknout žádný funkční celek. Např. ZŠ v Kroměříži má ve svém ročním plánu na březen naplánováno téma ochrany zvířat, projekt ozón a výsadbu stromků, na duben téma obalů, ekologickou olympiádu, brigádu v okolí školy, sběr hliníku, ukázky dravců, vítání jara, výlet do přírody a exkursi do Sladoven. (Krist, 2004) Nejde o to, že by jednotlivé aktivity byly špatné, ale spíše o absenci jejich kontextu - zařazení do smysluplného celku, směřujícího k jasně definovaným výchovně vzdělávacím cílům. Jak ale takový smysluplný rámec ve školních podmínkách vytvořit?

Zjevně lepším postupem je pokusit se připravit tematicky orientované celky. Například ZŠ v Mostě (Strnadová, 2004) vybrala pro rok 2003/4 čtyři hlavní témata, která procházela všemi ročníky a předměty, tj. Voda, obaly, vzduch, půda. Podle ročního plánu školy odpovídaly tomuto tématu aktivity: sledování teplot, srážek, $\mathrm{pH}$, návštěva Aquadromu, hudební výchova s písničkami, prezentace učební pomůcky - vodního kufř́íku. Z uvedeného zdroje není jasný jiný důvod zařazení uvedených aktivit, než souvislost $\mathrm{s}$ vodou. Ale ani takový přístup není dostačující, pokud jasně nedefinuje, jaké znalosti související s vodou by žáci měli mít, s jakými postoji k vodě by měli být konfrontováni, jaké dovednosti související s vodou by měli získat. Z těchto otázek mưžeme také vidět limity tematického přístupu: je například smysluplné mluvit o postojích k vodě odděleně od postojů k jiným složkám př́rody? Neměly by tedy výše uvedeným tématům předcházet ještě cíle vyšší úrovně, definující žádoucí postoje k životu, prírodě, sobě atd.? 


\section{Absence evaluačních nástrojů}

Slabá vazba mezi cíli a prostředky je dále umocněna nedostatečnými evaluačními nástroji. Ty jsou velmi často zaměřeny pouze na to, jak se program líbil žákưm nebo dohlížejícímu učiteli. Například z výsledků vyhodnocování projektu, který prezentovala Ružeková (Ružeková, 2003) vyplynulo, že: "Nejvíce žáků (32,56\%) konstatovalo, že projekt byl zajímavý a při jeho řešení se dozvěděli nové informace. 31,40\% žáků však tvrdí, že je projekt nezaujal ani se nic nového nedozvěděli. Zajímavé je, že poměrně mnoho žáků $(25,58 \%)$ se přiklonilo k tvrzení, že projekt byl sice zajímavý, ale o nové informace je neobohatil. (...) Z předcházejících analýz můžeme konstatovat, že zajímavý environmentální projekt obohatil většinu žáků o nové informace o životním prostředí městské krajiny."

Autorka při evaluaci používá dotazníkovou metodu a dva základní indikátory. První směřuje k ověření, zda se účastníkům program líbil. Není ošidnější indikátor výchovného projektu. Dětem se samozřejmě líbí být venku a je to pro ně oživující změna proti tradiční frontální výuce. Pokud ale cílem environmentální výchovy není zabavit děti, je třeba její efektivitu měřit jinak.

K tomu směřuje druhý indikátor, který se snaží ověřit míru dosažení vzdělávacích cílů projektu. Bohužel to dělá zpưsobem, který má v podstatě nulovou vypovídací hodnotu. $Z$ prezentace se tak ve skutečnosti nedozvíme, jestli projekt byl skutečně úspěšný či nikoliv, nedozvěděla se to ani jeho autorka, přestože na to měla opačný názor.

Širší paletu evaluačních nástrojů nabízí Hruška (2006): dotazník pro učitele, zaměřený na odbornost, přitažlivost a užitečnost programu, hodnocení žáky na principu terče - co a jak se jim líbilo - a srovnávací tabulky hodnotící náročnost, užitečnost, zajímavost a líbivost. Jiným doporučeným nástrojem byl autoevaluační formulář pro učitele. Žádný z uvedených nástrojů se nezaměřuje na dopady programu a míru splnění jeho vzdělávacích cílů.

Jiným ošidným indikátorem jsou kvantitativní údaje o počtu akcí a dětí za danou časovou jednotku. $V$ rámci environmentální výchovy nelze spoléhat na očistnou funkci "tržních vztahů", kde by konkurence zvyšovala kvalitu a školy by si vybíraly to nejlepší z nabídky. Dưvody jsou na obou stranách: nabídka je málo různorodá, současně ve většině krajů nepůsobí tolik středisek, aby si vzájemně konkurovaly. Poptávka je málo informovaná: školy nevědí, co mohou chtít, didaktická úroveň většiny středisek kontrastuje s převládajícím tradičním duchem výuky na školách, některé školy přistupují k environmentální výchově dost formálně a je jim vlastně jedno, co kupují. Z údajů o počtech dětí se ale nedozvíme o tom, jaký reálný dopad na jejich porozumění, postoje, dovednosti či jednání program měl.

Bohužel takové vyhodnocování není jednoduché. V zahraničí můžeme sledovat posun od kvantitativních nástrojů k nástrojům kvalitativním, jako je analýza volného textu, strukturované rozhovory či případové studie. (Hart a Nolanová, 1999) Tyto nástroje by se měly stát integrální součástí každého projektu a jejich výsledky by měly být využívány pro evaluaci práce celého střediska.

\section{Absence kritiky a výzkumu}

„Musím říct, že i přes veškerou chválu, kterou Zelený balíček všichni na jeho pražském uvedení zahrnovali, mě o svých kvalitách nepřesvědčil. Myslím, že pokud se má stát Zelený balíček užitečnou pomůckou pro učitele $i$ děti základních škol - a moc bych mu to prála - pak je teprve $v$ půli cesty a autory čeká ještě velký kus práce. $V$ současné podobě může napáchat více škody než užitku. Mohlo by se zdát, že jsem na Zelený balíček nasadila přliš̌ prísný metr, ale je třeba si uvědomit několik souvislostí: Zelený balíček není něco, co se muselo rodit na koleni, $v$ časovém stresu a bez finančního zajištění. V roce 2002 dostal REC na rozvoj a distribuci Zelených balíčku pro Českou 
Republiku a Slovensko grant ve výši 225.000 USD. Proto by tomu mělo odpovídat i měřítko nároků na kvalitu. Zelený balíček není určen k jednorázovému použití a jedná se o materiál komplexní, takže pokud ho školy přijmou, tak je velmi nepravděpodobné, že by byly $v$ dohledné době ochotné pořizovat si ještě nějaký jiný, i když třeba kvalitnější. Zelený balíček tak může ovlivnit výuku na školách na mnoho let dopředu." (Klonfarová, 2005)

Výše uvedený citát je příkladem dobré, ale v České republice málo rozšířené konstruktivní kritiky programů a publikací environmentální výchovy. Kritika přitom je standardním mechanismem zpětné vazby, kterou si navzájem dává komunita pưsobící v určitém oboru.

Určitým důvodem slabé kritiky je relativní selhání pedagogických fakult jako přirozeného garanta výzkumu a odbornosti $v$ oblasti environmentální výchovy. Vysokým školám se bohužel nepodařilo za patnáct let svobodné existence přijít s takovými impulsy, které by výrazněji ovlivnily praxi či zpưsob chápání environmentální výchovy u nás. Výsledkem je stav, který není optimální: s novými podněty přicházejí střediska ekologické výchovy a vysoké školy je pak přebírají, učí studenty a transformují do pedagogické terminologie. Současně střediska v problémech rutinního provozu a neustálých finančních problémů mají jen omezené možnosti nadhledu nad svoji prácí, analýzy zahraniční literatury, přemýšlení nad základními východisky své práce. Spolu s dalšími zmíněnými problémy se tak snadno mưže stát, že inovativní síla a kreativita, kterou se environmentální výchova u nás vždy vyznačovala, se oslabí, programy upadnou do stereotypního opakování zaběhaných postupů a výsledkem budou programy vysoké počtem, ale nízké kvalitou.

Jedním z cílů časopisu Envigogika je právě poskytnout pro takovou kritiku platformu.

\section{Závěr}

Cílem textu bylo poukázat na slabá místa v teorii a praxi environmentální výchovy $v$ České republice. Ty byly nalezeny zejména $v$ nedostatečné vazbě mezi cíli a prostředky, slabé metodice, neefektivních programech, absenci kritiky a významnějšího vědeckého výzkumu. Článek úmyslně pomíjel všechny silné stránky praxe environmentální výchovy, kterých je rozhodně více, než popsaných slabin. Kritické připomínky $v$ něm byly míněny jako konstruktivní návrhy směřující k vylepšování současného stavu.

Jednotlivé kritické oblasti je přitom třeba chápat spíše jako hypotézy - každá z nich by se mohla stát předmětem samostatného výzkumu. Řada dalších témat, jejichž otevření vyžaduje důkladnější analýzu, byla v článku záměrně opomenuta. Předmětem dalších průzkumů by se tak mohla stát např́klad problematika metodických rámců uplatňovaných středisky ekologické výchovy (uplatňuje se více transmisivní či konstruktivistická metodika?), různosti uplatňovaných přístupů (Dominují v současné nabídce programy vycházející z pozitivistického chápání environmentální výchovy? Jaké je rozšíření jiných přístupư?) či téma odborné kvalifikace lektorů (Převažují mezi lektory spíše odborníci na biologii nebo učitelé?). Zodpovězení těchto otázek by mohly přinést samostatné výzkumy.

\section{Literatura:}

- Činčera, J. (2007). Environmentální výchova: Od cílů k prostředkům. Brno: Paido.

- Daňková, Lenka (eds.), (2004). Škola pro život. Př́ručka k realizaci školních programů ekologického/environmentálního vzdělávání, výchovy a osvěty a výchovy k udržitelnému způsobu života. Praha: Sdružení středisek ekologické výchovy Pavučina.

- Hart, P., \& Nolan, K. (1999). A Critical Analysis of Research in Environmental Education. Studies in Science Education, 34(1), 1-69. Retrieved from 
http://www.tandfonline.com/doi/abs/10.1080/03057269908560148 http://dx.doi.org/10.1080/03057269908560148

- Horká, H. (2005). Ekologická dimenze výchovy a vzdělávání ve škole 21. století. Brno: Masarykova univerzita.

- Hruška, J. (2006). Globální a environmentální výchova na pobytových akcích. Pardubice: Ekocentrum PALETA.

- Klonfarová, H. . Zelený balíček do škol? EkoList po drátě. Zelený knihomol. . Retrieved from http://www.ekolist.cz/kn-rec-0503.shtml

- Kolářová, H. (2005). Měnící se vzdělávání pro měnící se svět. Bedrník, 3(4),

- Krist, P. (2004). Environmentální výchova na základní škole Kroměříž, Albertova 4062. Učitel a vzdělávání pro udržitelný rozvoj, 279-282.

- Máchal, A. (2000). Praktická ekologická výchova. Brno: Rezekvítek.

- Matre, S. v. (1999). Earth Education: A new beginning. Greenville: The Institute for Earth Education.

- Nádvorník, O., \& Volfová, A. (2004). Globální rozvojové vzdělávání. Praha: Člověk v tísni.

- Nádvorník, O., \& Chára, P. (2006). Bohouš a Dáša proti chudobě. Praha: Člověk v tísni.

- $\quad$ NP. Pojd'me na to od lesa (2003). Vimperk: Správa NP a CHKO ve Vimperku.

- Ružeková, M. (2003) Environmentálne projekty očami dětí. In Cesty demokracie vo výchove a vzdelávaní VIII (p. 73). Bratislava: Univerzita Komenského.

- Sever, (2006). Týden pro udržitelný život. Horní Maršov: SEVER.

- StrnadovÁ, I. (2004) Výchova k udržitelnému rozvoji na Základní škole v Mostě. In Učitel a vzdělávání pro udržitelný rozvoj (pp. 297-300). .

\section{Recenzní posudky (souhrnná slovní hodnocení a doporučení)}

Pozn.: Recenzní posudky se týkají pưvodní verze př́spěvku, tj. před zapracováním pripomínek posuzovateli̊.

\section{Recenzent 1:}

Přijatelné s drobnými úpravami:

$K$ nejcennějším přínosům recenzovaného textu patří zřetelné pojmenování řady skutečně existujících problémů a mýtů, kterými je EV zatížena, a vybídnutí k diskusi nad spornými či diskutabilními tezemi. Taková diskuse je pro EV nanejvýš potřebná. K jejímu urychlení mohou přispět výborné i poněkud sporné části textu, např.:

- část 2: domnívám se, že smyslem ani snahou současné EV není a nemělo by být "ovlivňování postojü" jako spíše "podílet se na osvojování kompetencí souvisejících s ekologicky príznivějšími zpưsoby života" (pozn. AM) - prijimeme-li tento prístup, pak autorem vznesená otázka "Měla by se EV soustředit na ovlivňování postojů a pokud ano, tak jakých a odkud k tomu bere právo?" se může stát bud' bezpředmětnou anebo přinejmenším méně vyhrocenou. Ostatně, kde "berou právo" výchova sexuální, multikulturní a jiné?

Nemohu souhlasit s tvrzením, že „chápání rostlin a živočichů jako přírodních zdrojů je právě dưsledkem panského postoje k přírodě". Označujeme-li cokoliv (živého) jako přirodní zdroj, může to přece vypovídat také o tom, že jsme si vědomi nezměritelné a nenahraditelné hodnoty živých organismů pro udržitelný život planety Země. 
Existuje vůbec něco jako "neantropocentrický slovník"? Jsme skutečně schopni uvažovat a mluvit jinak než "člověkostředně", biocentricky či ekocentricky, s výjimkou akademických seminářu ekologické etiky? Pro praktické výukové účely se domnívám, že se lišíme spíše jen hloubkou či mírou přiznání svého antropocentrismu, resp. úrovní jeho vědomého potlačení.

Naopak za výtečnou považuju poznámku k jednotě cílů a prostředků EV na konci tohoto oddílu.

- část 3: Přiznávám svoji značnou obezřetnost vưči vymezování jednotlivých směrů EV, která pramení ze skutečnosti, že se $v$ praxi setkáváme nejen $s$ jejich různými kombinacemi, ale především různými odstíny. Abychom mohli vést smysluplnou diskusi nad označeními a charakteristikami jednotlivých směrů EV, bude potřebné se nejprve shodnout na jejich cílech a obsazích, jinak si pořád budeme "mlet každý to své" - což budiž autorovi dáno jako námět pro jeho další úvahy.

Nesdílím autorovu obavu z používání simulačních her učitelem vyznávajícím pouze svoji "centrální roli", obavu považuju za hypotetickou - a naznačované riziko za minimální. (Ostatně, žádná aktivita se nemusí vždy podařit jakémukoliv lektorovi, ani když nedojde k žádné $z$ autorem popisovaných vražedných kombinací př́stupů $k$ EV.)

Uznávám, že je zapotřebí uvědomovat si "rưznosti svých cest", jejich "násilného spojování" se však neobávám, nebot’ předpokládám, že existuje-li (nepsaná) dohoda o cílech EV (a jsou-li tyto cíle sbíhavé nebo dokonce společné, což věřím - a je to rovněž námět pro další společnou diskusi a studium zahraniční literatury), pak se prostředky k jejich naplnění nemohou odlišovat natolik, aby se navzájem potíraly.

-část 5: velmi živě souhlasím s autorovým dưrazem na potřebu posuzování a vyhodnocování kvality a účinnosti EV, které dosud prakticky neexistují (což je však problémem celého českého školství, jež, až na výjimky, hodnotí pouze míru nabytých vědomostí a osvojených dovedností). Častá argumentace poptávkou převyšující nabídku SEV je podle mého soudu zcela lichá a je zapotřebí ř́ci to nahlas přesně tak, jak činí autor.

- části 6 a 7: obdobně oceňuju zdưraznění potřeby kontextu mezi výukovými programy nabízených středisky EV a školními programy EV, jakož i potřebu většího kvalifikovaného podílu pracovníků SEV na tvorbě ŠVP jednotlivých škol; úspěšnost takové spolupráce, stejně jako kvalita výukových programů SEV, jsou podmíněny alespoň základní orientací v metodických postupech, požadavcích a obsazích RVP.

- část 8: bez konstruktivně kritického dialogu se nemůže vyvíjet žádný pedagogický obor, proto je zcela na místě nabádat $k$ otevřené diskusi nad mnoha úskalími, obtížemi a neduhy naší současné EV, a zejména podporovat dosud ne vždy velkou vưli ekopedagogů k takovým debatám i $k$ větší otevřenosti vưči zkušenostem ze zahraničí.

\section{Aleš Máchal}

\section{Lipka - dům ekologické výchovy}

\section{Recenzent 2:}

*Spolehlivost odkazů a informací je vysoká, s dílčí výhradou k ilustraci stavu české ekologické výchovy na překladu německé publikace „Pojd'me na to od lesa"

*Použitá metodologie: relevance pro výzkumnou otázku, jasnost a jednoznačnost provedení, čistota závěrư: střední - jde o osobní posouzení situace provedené jediným autorem, posouzení je opřeno o předchozí studium teoretických a metodologických publikací. Větší relevanci by pochopitelně mělo širší zhodnocení posuzovaných programů 
podle jasně stanovaných kritérií. To však nebylo v daném čase pravděpodobně možné a je spíše námětem pro budoucnost.

*Příspěvek je mimořádně cenný tím, že se věnuje problematice zatím u nás systematicky neřešené - totiž identifikaci slabých míst $v$ teorii a praxi české ekologické výchovy, a to především na úrovni základních a středních škol (ve střediscích ekologické výchovy i ve školách samotných). Metodicky je příspěvek postaven na osobním posouzení situace autorem, což Ize vnímat jako určitou slabinu. Optimem by samozřejmě byla šířeji založená studie posuzující vybrané programy podle metodiky s jasně stanovenými kritérii. Vzhledem k tomu, že byl článek zamýšlen jako první otevření odborné diskuse nad kvalitou programů ekologické výchovy (sám autor jej označuje jako „vstupní úvahu") je však i $v$ této podobě aktuální. Jde de facto o soupis několika hypotéz, které by se mohly stát předmětem budoucích výzkumů.

*Některá tvrzení autora jsou v kontextu toho, že nejde o výsledek výzkumu, ale o osobní úvahu, resp. o pracovní hypotézy, příliš kategorická. Jako zjednodušující se mi jeví mj. tvrzení autora, že použití pojmu „přírodní zdroj" je nutně "důsledkem panského postoje k přírodě". Na rozdíl od autora se domnívám, že obdobný pohled může být součástí např. i postoje "správcovského" (= spravujícího "zdroje" nejen pro sebe, ale i pro jiné) a že Ize navíc kombinovat pohled na prírodu jako hodnotu samu o sobě a zároveň jako hodnotu pro člověka. Polemizovat Ize i s názorem, zda atraktivita programu („zda se program líbil") či poptávky po programech přece jen není jedním z užitečných indikátorů kvality programu (s autorem Ize však souhlasit, že jde často o jediné používané ukazatele a že nevypovídají mnoho o dosažení vzdělávacích cílů). Přes shodný pocit s autorem, že bývá často zaměňován cíl a téma a že nutně každý př́rodovědný program nemusí být ekologickou výchovou, by mělo být předmětem budoucího výzkumu, zda v kontextu současného rychlého „odcizování přírodě" nemá nakonec vnášení čehokoli „přírodního" do výuky (ad absurdum i "čtení jednoduchých vět o zvíratech") prínos pro „formování proevnironmentálních postojü".

*Z drobnějších věcných připomínek: Publikace „Pojd'me na to od lesa" není dobrým příkladem úrovně české, ale spíše německé ekopedagogiky, protože jde jen o mírně doplněný a upravený překlad pưvodní práce.

Z jednotlivých podnětů za velmi cenné (a nejobjevnější) považuji zejména upozornění na převažující útržkovitost a absenci kontextu u mnoha programủ ekologické výchovy ve školách i ve střediscích ekologické výchovy (viz části "Preference krátkých výukových programů" a "Slabá metodika projektů a školních plánů environmentální výchovy").

\section{Jiří Kulich, SEVER}


Časopis Envigogika vydává Centrum pro otázky životního prostředí UK. Vývoj časopisu je podpořen projektem OP VK Mezioborová sít udržitelného rozvoje.

Více najdete na internetových stránkách projektu mosur.czp.cuni.cz
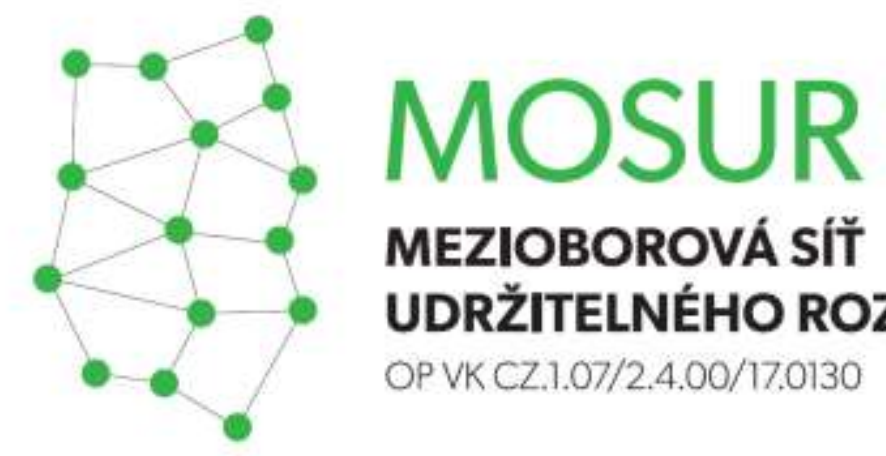

\section{MEZIOBOROVÁ SÍT} UDRŽITELNÉHO ROZVOJE

OP VK CZ.1.07/2.4.00/17.0130
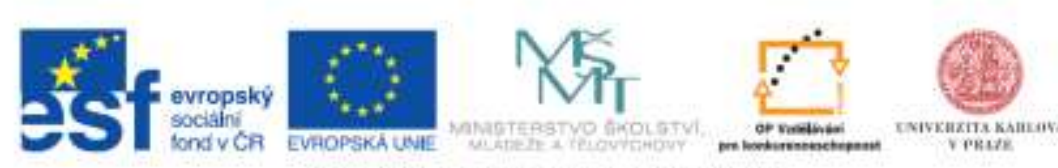

INVESTICE DO ROZVOUE VZDELAVANI 